\title{
EKSISTENSI GOSIP DI MEDIA SOSIAL DALAM MENENTUKAN RETURN SAHAM DI BURSA EFEK INDONESIA DAN PERSISTENSI PENGARUHNYA BERSAMA HARI BURSA
}

\author{
Sawidji Widoatmodjo dan Halim Putera Siswanto \\ Fakultas Ekonomi Universitas Tarumanagara \\ sawidjiw@pps.untar.ac.id
}

\begin{abstract}
It isn't easy to define whether a stock return is determined by a certain factor or trading days. There were many research evidence that some factors had influenced stock return. There were also, however, many researches on stock return anomaly providing the facts that stock return, especially their abnormal returns, were caused by specific trading days, such as week-day effect, January effect, and many others. This research attempts to explore this logic. We tested the impact of gossips that spreaded-out through social media, as a certain factor, and all trading days in a week to a stock return. We used the gossips in social media as response of the massive use of the internet in stock investment. The existence of the gossips is more strengthened by the existence of noise traders. Nowadays, noise traders use the internet, such as mailing list, message board, facebook, and others, that are called as social media, as a media to spread gossips. This research investigates whether gossips spreaded through mailing list have a role in mispricing, so then it can be used to determine the stock return. If they have the role, then how long is the persistence? To anticipate the impact of trading days, this research also includes trading days as a control variable. Using multivariate statistical technique and combined with event study with five windows (five days before and after a gossip has been posted), this research analyzes the stock return that gets the most gossips posted by investors. The result suggests that the gossips in social media don't show significant influence on the stock return, and automatically no persistence exists. Based on that result, the conclusion is that the gossips in social media can't be used to determine the stock return. The implication is that even social media can facilitate the stock transaction better, the investors in Indonesia Stock Exchange can't exploit the gossips in social media for taking profit through behaving as noise traders.
\end{abstract}

Kata kunci: saham, imbal hasil, gosip, media sosial

\section{PENDAHULUAN}

Tidaklah mudah untuk menentukan sebenarnya faktor apakah yang dapat menentukan imbal hasil (return) dari investasi saham. Sejumlah penelitian yang melibatkan berbagai faktor telah banyak dilakukan oleh para akademisi. Semantara itu, para praktisi juga telah banyak melahirkan strategi untuk dapat mendapatkan imbal hasil investasi saham yang tinggi. Namun hasil penelitian dan strategi tersebut masih menyisakan perdebatan, sehingga belum dapat menjawab pertanyaan, sebenarnya faktor apakah yang menentukan imbal hasil dari investasi saham ini.

Faktor gosip juga sudah digunakan dalam penelitian dalam menentukan imbal hasil saham, namun jumlahnya tidak sebanyak faktor-faktor yang lain, terutama faktor-faktor fundamental, seperti Return on Asset (ROA), Price Earning Ratio (PER), Debt-to-Equity 
Ratio (DER), dan lain sebagainya, termasuk struktur modal. Dari yang sedikit itu pun belum memberikan hasil yang memuaskan. Ada peneliti yang menemukan adanya pengaruh gosip terhadap imbal hasil saham, tapi tidak sedikit pula yang tidak menemukan kaitan seperti itu.

Di sisi lain, kalaupun ada keterkaitan antara gosip dengan imbal hasil saham, belum dapat dipastikan apakah pengaruh tersebut dapat berdiri sendiri atau ada dukungan dari faktor lain, terutama hari bursa. Artinya, apakah imbal hasil saham yang tinggi itu akibat adanya gosip yang membicarakan saham tersebut, atau kebetulan hari-hari tertentu di bursa memang harga-harga saham sedang meningkat, sehingga banyak investor yang dapat memetik imbal hasil yang tinggi. Dengan demikian, sebenarnya diperlukan riset yang dapat memisahkan apakah imbal hasil saham ditentukan oleh gosip atau hari bursa.

Masalah lain, berapakah lamanya (persistensi) pengaruh gosip dan hari bursa tersebut? Seandainya sebuah gosip dapat memiliki pengaruh yang panjang terhadap imbal hasil saham, maka investor dapat memanfaatkan situasi ini dengan menahan investasi tersebut sampai menjelang hilangnya pengaruh. Idealnya, investor dapat menjual ketika harga mencapai puncak tertingginya. Hal ini hanya dapat diketahui apabila diketahui pesistensi pengaruh dari sebuah faktor.

Secara formal, yang ingin dijawab melalui penelitian ini adalah, apakah benar gosip di media sosial dapat menentukan return saham? Apabila dapat, seberapa lama keberadaannya? Apakah justru sebenarnya yang menentukan return saham tersebut adalah hari bursa? Apabila ya, berapa lama pula ketahanannya?

Adapun perbedaan dengan penelitian yang terdahulu adalah: pertama, penelitian terdahulu banyak mengunakan data keuangan masa lalu sebagai informasi publik. Dalam penelitian ini yang digunakan sebagai informasi publik adalah gosip yang disebarkan melalui media sosial, tepatnya mailing list (milis). Kedua, penelitian terdahulu tidak membedakan kondisi pasar bullish dan bearish. Dengan demikian, pada penelitian ini kedua kondisi tersebut dicoba untuk diuji masing-masing untuk kemudian diselidiki perbedaannya.

Setelah ini, bagian-bagian yang akan dibahas adalah kajian teori, metode penelitian, hasil dan pembahasan serta penutup (simpulan dan saran).

\section{KAJIAN TEORI}

Keberadaan rumor sebagai bagian dari kehidupan bermasyarakat sudah ada sejak lama. Rosnow (1988; 1991; 2001) dan DiFonzo \& Bordia (1997) mendefinisikan rumor sebagai informasi yang tidak (dapat) dikonfirmasi; bersifat lokal, baru atau penting; direncanakan untuk dipercaya. Gosip meski sering disamakan dengan rumor, yang menurut Wert \& Salovey (2004), cenderung memiliki inner circleness, sehingga biasanya hanya beredar diantara orang-orang yang memiliki historis yang sama atau kepentingan yang sama.

Para investor adalah kumpulan orang-orang yang memiliki historis (sebagai investor) yang sama dan kepentingan yang sama pula, maka istilah gosip lebih tepat digunakan dalam pembicaraan menyangkut investasi keuangan. Itulah sebabnya mengapa Wysocki (1998) menggunakan istilah cyber gossip untuk menyebut rumor yang disebarkan melalui berbagai wahana posting di internet. 
Gosip dalam Investasi Saham. Meski gosip merupakan informasi yang tak dapat dikonfirmasi (kebenarannya), isi gosip tersebut dapat mempengaruhi individu (DiFonzo and Bordia 1997; Koenig 1985; Rosnow 2001). Secara faktual pun, peran gosip dalam investasi saham bukanlah hal yang baru. Peristiwa pertama yang melibatkan gosip dalam investasi saham terjadi di bursa Amsterdam pada tahun 1600-an. Ketika itu hanya ada dua saham yang diperdagangkan-Dutch East India Company dan Dutch West India Company. Gosip mulai menyebar di Amsterdam Coffee House sejak kapal berlayar dan spekulasi pun dimulai, dengan menebak apakah yang dimuat oleh kapal-kapal tersebut (Leinweber dan Madhavan, 2001)?

Namun, melakukan investasi saham berdasar gosip, bukan merupakan tradisi yang berlaku di dunia investasi keuangan. Menurut Jones (2004: 11), bagian pertama dari proses keputusan investasi adalah melakukan penilaian (valuation) dan analisis sekuritas secara individu. Bagian kedua, model penilaian yang diaplikasikan pada penilaian sekuritas ini adalah mengestimasi harga dan nilainya.

Jadi jelaslah bahwa melakukan investasi idealnya didasarkan pada fundamental keuangan perusahan. Jika demikian, apakah dapat dikatakan sebagian besar investor telah menyalahi prosedur proses investasi? Jones sendiri dapat menerima kondisi ini. Menurutnya, melakukan penilaian dan analisis bukanlah pekerjaan mudah. Hal ini memerlukan pengetahuan tentang laporan keuangan perusahaan dan kemampuan menganalisisnya. Padahal Rose (2001) dan Rose et. al (2004) menemukan fakta bahwa sebagian investor tidak memahami dan tidak mampu menganalisis laporan keungan perusahaan. Epstein dan Pava (1994), misalnya, menyatakan mendekati 30\% investor di AS mengalami kekurangan pengetahuan yang diperlukan untuk memahami dasar-dasar laporan keuangan. Hawkins and Hawkins (1986) juga melaporkan lebih dari 50\% investor AS hanya membaca sekilas laporan tahunan tanpa menganalisisnya.

Hal ini merupakan salah satu faktor yang menyebabakan sebagian investor tidak menggunakan prosedur proses investasi ideal seperti yang dimaksud oleh Jones (2014). Sebagai gantinya, para investor mengambil keputusan investasi atas dasar gosip.

Gosip di Media Sosial. Makin besarnya peran investor individu dan makin pentingnya peran gosip telah meningkatkan pemanfaatan wahana posting (investor dapat mendownload newsgroups, menjelajahi website, membuka blog, berlangganan mailing list, bergabung dengan message board, facebook, blackberry massager, whatspp, twitter, dan lain sebagainya) untuk mendapatkan gosip (Hodge and Pronk, 2006) atau cyber gossip (Wysocki, 1998). Hal ini ditandai dengan terus meningkatnya jumlah pesan yang dikirim (posting) oleh investor ke message board-situs tempat investor melakukan posting. Menurut catatan Harmon (1998, 1 September), jumlah posting sudah mencapai ribuan per hari pada tahun 1998, padahal dua tahun sebelumnya belum dikenal atau tidak terdapat satu pun posting soal investasi saham ini. Kurun waktu dua tahun berikutnya (1999-2001) jumlah posting sudah mencapai lebih 35 juta (Antweiler \& Frank, 2002a). Sampai Februari 2006, diperkirakan 12 juta poster terdaftar di Yahoo! Finance (http://finance.yahoo.com) saja.

Yang menjadi persoalan adalah bahwa selama ini gosip di media sosial dipersepsikan sebagai "informasi sampah", sebagai sumber rumor yang tidak mengandung substansi, menambah kacau (noise) arus informasi, sehingga dikonotasikan negatif (Crawford 1999). Bahkan Dewally (2003) tegas menyatakan tidak menemukan fakta rekomendsi dari posting memiliki nilai informasi. Namun ada juga yang merasa mendapat manfaat dari 
diskusi secara online itu. Kelompok ini beranggapan informasi yang di-posting menyediakan forum yang memungkinkan investor mengambil saripati dari informasi yang ada (Das et. al, 2005). Atau paling tidak menjadi peringatan dini, seperti yang terjadi pada skandal Enron (Felton \& Kim, 2002). Mungkin ini yang menjelaskan, meski menurut Barber \& Odean (2000) berinvestasi secara online menurunkan kemampuan investor dalam mendapatkan keuntungan, namun tidak menurunkan migrasi cara berinvestasi dari menggunakan telepon menjadi menggunakan internet.

\section{KAJIAN TEORI}

Return saham diketahui sulit untuk diprediksi. Apakah posting di media sosial dapat digunakan untuk memprediksi return saham? Diantara penelitian mengenai posting, belum ditemukan kata sepakat. Fisher \& Statman (2000) menemukan bahwa sentiment dari investor individu dan institusi dapat digunakan untuk menentukan return saham. Wysocki (1998) menyimpulkan, volume posting dapat digunakan untuk menenetukan return saham.

Namun Tumarkin dan Whitelaw (2001) tidak menemukan bukti bahwa sentiment dapat digunakan untuk menentukan return saham. Demikian pula dengan Das \& Chen (2001) dan Antweiler \& Frank (2002).

Antweiler \& Frank (2004 b), menemukan ada korelasi negatif antara posting dengan return saham, namun untuk memprediksi ditemukan adanya pengaruh negatif yang signifikan, meskipun dengan magnitude yang kecil. Sebaliknya, posting positif berpengaruh secara positif dan signifikan terhadap return saham.

Das et. al (2005) menyatakan bahwa jumlah posting berkorelasi negatif dengan return saham pada hari yang sama, tetapi berkorelasi positif dengan hari sebelumnya. Dewally (2003) menemukan bahwa rekomendasi positif mengiringi kinerja yang baik atas sahamsaham yang ditelitinya. Berkaitan dengan hipotesis momentum, kinerja saham yang buruk mendahului rekomendasi negatif, tetapi hal ini tidak signifikan. Selanjutnya, konsisten dengan hipotesis no-value, rekomendasi negatif diikuti dengan CAR (Cummulative Abnormal Return) campuran (positif dan negatif), dan tidak signifikan, meskipun signifikan pada hari pertama hingga hari ke 20 pada pasar dengan mood yang buruk.

Atas dasar temuan-temuan di atas, maka dapat dibangun hipotesis sebagai berikut:

$\mathrm{H}_{1}$ : Posting beli dari $\mathrm{t}_{-5}$ sampai $\mathrm{t}_{+5}$ dapat digunakan untuk menentukan return saham pada kondisi pasar Bullish

$\mathrm{H}_{2}$ : Hari bursa dari $\mathrm{t}_{-5}$ sampai $\mathrm{t}_{+5}$ berpengaruh positif terhadap return saham pada kondisi pasar Bullish

$\mathrm{H}_{3}$ : Posting jual dari $\mathrm{t}_{-5}$ sampai $\mathrm{t}_{+5}$ dapat digunakan untuk menentukan return saham pada kondisi pasar Bearish

$\mathrm{H}_{4}$ : Hari bursa dari $\mathrm{t}_{-5}$ sampai $\mathrm{t}_{+5}$ berpengaruh positif terhadap return saham pada kondisi pasar Bearish

\section{METODE PENELITIAN}

Populasi dan Sampel. Populasi penelitian ini adalah seluruh saham yang terdaftar di Bursa Efek Indonesia. Namun, tidak semua saham mendapatkan posting. Dari sahamsaham yang mendapatkan posting, jumlah posting yang diperoleh belum tentu dapat 
memenuhi ketentuan yang diinginkan. Oleh karena itu, untuk kepentingan signifikansi maka peneltian ini mengambil sampel sebagai basis penelitian.

Adapun teknik sampling yang digunakan adalah purposive sampling dengan kriteria berupa saham yang mendapat posting beli terbanyak pada kondisi pasar bullish dan saham yang mendapat posting jual terbanyak pada kondisi pasar bearish. Kriteria seperti ini dilakukan karena tidak semua saham mendapatkan posting yang seimbang. Wysocki (1998) mengakui bahwa sebenarnya tidak terlalu banyak investor yang melakukan posting. Posting yang ada pun hanya terkonsentrasi pada lima perusahaan (Apple Computer, Intel, Oracle, Starbucks dan MCI Worldcom. Pada Wysocki (1999), misalnya, Dell Computer mendapatkan posting 1.740 pada 18 Agustus 1998, sementara USX - grup perusahaan baja—-hanya mendapatkan dua posting.

Pengumpulan Data. Data yang digunakan di dalam penelitian ini terdiri dari dua jenis, yaitu data primer dan sekunder. Data primer adalah berupa jumlah posting beli dan posting jual. Data ini diambil dari mailing list : Junior Trader@yahoogroups.com, yang mulai aktif sejak 3 Maret 2002.

Data dikumpulkan mulai 1 Maret 2007 hingga 30 Juni 2007 dan 1 Maret 2008 hingga 30 Juni 2008. Data ini dibagi menjadi dua periode, yaitu periode pertama, 1 Maret 2007 hingga 30 Juni 2007, mewakili periode bullish. Periode kedua, 1 Maret 2008 hingga 30 Juni 2008, mewakili periode bearish. Dengan demikian panjang data yang dikumpulkan adalah enam bulan. Panjang data demikian mengikuti sebagian besar penelitian yang menggunakan data message board..

Data sekunder adalah berupa harga saham harian, yang dikumpulkan dari Yahoo! Finance. Periode data yang dikumpulkan adalah sama dengan periode data jumlah posting, yakni dari 1 Maret 2007 hingga 30 Juni 2007 dan dari 1 Maret 2008 hingga 30 Juni 2008.

Adapun kriteria mengenai posting beli dan posting jual adalah seperti yang terlihat pada Tabel 1. Pekerjaan pemilhan posting ini yang paling berat dalam penelitian yang menggunakan data posting di internet. Sebelum memilahkan data, dibuat terlebih dahulu kategori pemilihan posting menjadi empat bagian, yakni: beli, jual, netral, dan lainnya. Sebagian besar penelitian sebelumnya menggunakan kategori ini (misalnya, Das et. al, 2005; Das \& Chen, 2001; Fisher \& Statman, 2000; Sehgal dan Song, 2007), namun demikian dalam apakah suatu posting masuk ke dalam kategori beli, jual, atau netral, terdapat perbedaan diantara penelitian tersebut.

Tabel 1. Kategori Posting

\begin{tabular}{|c|c|}
\hline \multirow[t]{3}{*}{ Kategori } & Kalimat Posting Mengandung \\
\hline & 1. Kata-kata: beli; bullish \\
\hline & 2. Nada kalimat optimis \\
\hline \multirow[t]{6}{*}{ Beli } & 3. Kalimat pernyataan positif \\
\hline & 4. Berita baik \\
\hline & 5. Pernyataan memiliki saham \\
\hline & 6. Merespon negatif atas posting jual \\
\hline & 1. Kata-kata: jual; bearish \\
\hline & 2. Nada kalimat pesimis \\
\hline \multirow[t]{4}{*}{ Jual } & Kalimat pernyataan negatif \\
\hline & 4. Berita buruk \\
\hline & 5. Pernyataan tidak memiliki saham \\
\hline & 6. Merespon negatif atas posting beli \\
\hline Netral & Kata-kata: hold, tahan, wait and see \\
\hline Lainnya & Selain kata, kalimat, pernyataan dan respon yang dimiliki ketiga kategori \\
\hline
\end{tabular}


Variabel \& Pengukuran. Tabel 2 memuat variabel, jenis dan pengukurannya yang digunakan dalam penelitian ini. Variabel utama yang digunakan untuk pengujian hipotesis dalam penelitian ini adalah gosip, yang dalam hal ini adalah berupa posting beli dan posting jual, serta nilai-nilai saham dalam bentuk abnormal return.

Tabel 2. Definisi Variabel dan Pengukuran

\begin{tabular}{|c|c|c|}
\hline $\begin{array}{l}\text { Variabel } \\
\text { Dependen }\end{array}$ & Definisi & Pengukuran \\
\hline $\begin{array}{l}\text { Abnormal Return } \mathrm{t} \\
\mathrm{AR}_{\mathrm{i}((\mathrm{t}-5)-(\mathrm{t}+5))}\end{array}$ & $\begin{array}{l}\text { Tingkat penghasilan suatu saham } \\
\text { pada hari ini sampai hari kelima }\end{array}$ & $\begin{array}{l}\text { Dihitung dari harga close-to-close } \\
\text { dengan rumus: } \\
A R_{\mathrm{i}(\mathrm{t}-5)-(\mathrm{t}+5))}=\mathrm{R}_{\mathrm{i}((\mathrm{t}-5)-(\mathrm{t}+5))}-\mathrm{a}-\mathrm{b}_{\mathrm{i}((\mathrm{t}-5)-} \\
(\mathrm{t}+5) \mathrm{RM}_{((\mathrm{t}-5)-(\mathrm{t}+5))}\end{array}$ \\
\hline \multicolumn{3}{|l|}{ Independen } \\
\hline $\begin{array}{l}\text { Posting beli } \\
\mathrm{P}_{\mathrm{bBul}}\end{array}$ & $\begin{array}{l}\text { Jumlah posting beli pada periode } \\
\text { bullish }\end{array}$ & $\begin{array}{l}\text { Total posting beli terbanyak sebuah } \\
\text { saham periode } 1 \text { Maret } 2007 \text { sampai } 30 \\
\text { Juni } 2007\end{array}$ \\
\hline $\begin{array}{l}\text { Posting jual } \\
\mathrm{P}_{\mathrm{jBear}}\end{array}$ & $\begin{array}{l}\text { Jumlah posting jual pada periode } \\
\text { bearish }\end{array}$ & $\begin{array}{l}\text { Total posting jual terbanyak sebuah } \\
\text { saham periode } 1 \text { Mei } 2008 \text { sampai } 30 \\
\text { Juni } 2008\end{array}$ \\
\hline \multicolumn{3}{|l|}{ Kontrol } \\
\hline Senin & Posting hari Senin (variabel dummy) & $\begin{array}{l}\text { Total posting yang diterima suatu saham } \\
\text { pada hari Senin, } 1 \text { Maret } 2007 \text { sampai } 30 \\
\text { Juni } 2007 \text {, untuk periode pasar bullish } \\
\text { dan } 1 \text { Maret } 2008 \text { sampai } 30 \text { Juni } 2008 \\
\text { untuk periode pasar bearish }\end{array}$ \\
\hline Selasa & Posting hari Selasa & $\begin{array}{l}\text { Total posting yang diterima suatu saham } \\
\text { pada hari Selasa, } 1 \text { Maret } 2007 \text { sampai } 30 \\
\text { Juni } 2007 \text {, untuk periode pasar bullish } \\
\text { dan } 1 \text { Maret } 2008 \text { sampai } 30 \text { Juni } 2008 \\
\text { untuk periode pasar bearish }\end{array}$ \\
\hline Rabu & Posting hari Rabu & $\begin{array}{l}\text { Total posting yang diterima suatu saham } \\
\text { pada hari Rabu, } 1 \text { Maret } 2007 \text { sampai } 30 \\
\text { Juni } 2007 \text {, untuk periode pasar bullish } \\
\text { dan } 1 \text { Maret } 2008 \text { sampai } 30 \text { Juni } 2008 \\
\text { untuk periode pasar bearish }\end{array}$ \\
\hline Kamis & Posting hari Kamis & $\begin{array}{l}\text { Total posting yang diterima suatu saham } \\
\text { pada hari Kamis, } 1 \text { Maret } 2007 \text { sampai } \\
\text { 30 Juni 2007, untuk periode pasar bullish } \\
\text { dan } 1 \text { Maret } 2008 \text { sampai } 30 \text { Juni } 2008 \\
\text { untuk periode pasar bearish }\end{array}$ \\
\hline Jum'at & Posting hari Jum'at & $\begin{array}{l}\text { Total posting yang diterima suatu saham } \\
\text { pada hari Kamis, } 1 \text { Maret } 2007 \text { sampai } \\
\text { 30 Juni 2007, untuk periode pasar bullish } \\
\text { dan } 1 \text { Maret } 2008 \text { sampai } 30 \text { Juni } 2008 \\
\text { untuk periode pasar bearish }\end{array}$ \\
\hline
\end{tabular}

Metode Analisis. Penelitian ini menggunakan mentode analisis multivariat, dengan mencari koefisien masing-masing variabel. Adapun langkah-langkah analsis yang akan dilakukan adalah sebagai berikut:

1. Men-download data primer dari mailling list Junior Trader, untuk mendapatkan variabel jumlah posting, jumlah posting beli dan posting jual. 
2. Men-download data sekunder dari Yahoo! Finance, untuk mendapatkan variabel return saham.

3. Melakukan pengukuran untuk masing-masing variabel.

4. Membuat tabulasi dari variabel yang telah diperoleh.

5. Melakukan regresi atas model-model yang dibuat.

Berikut adalah model-model regresi yang akan dihitung:

$\mathrm{AR}_{(\mathrm{t}-1)}=\alpha+\beta_{1} \mathrm{P}_{\mathrm{bbull}^{(t-1)}}+\beta_{2} \operatorname{Senin}_{(\mathrm{t}-1)}+\beta_{3} \operatorname{Selasa}_{(\mathrm{t}-1)}+\beta_{4} \operatorname{Rabu}_{(\mathrm{t}-1)}+\beta_{5} \operatorname{Kamis}_{(\mathrm{t}-1)}+\beta_{6} \mathrm{Jum}^{\prime} \mathrm{at}_{(\mathrm{t}-1)}+\dot{\varepsilon}_{(\mathrm{t}-1)} \ldots \ldots$ 1

$\operatorname{AR}_{(t-2)}=\alpha+\beta_{1} P_{\text {bbull(t-2) }}+\beta_{2} \operatorname{Senin}_{(t-2)}+\beta_{3} \operatorname{Selasa}_{(t-2)}+\beta_{4} \operatorname{Rabu}_{(\mathrm{t}-2)}+\beta_{5} \operatorname{Kamis}_{(\mathrm{t}-2)}+\beta_{6} \mathrm{Jum}^{\prime} \mathrm{tat}_{(\mathrm{t}-2)}+\dot{\varepsilon}_{(\mathrm{t}-2)} \ldots \ldots$ 2

$\mathrm{AR}_{(\mathrm{t}-3)}=\alpha+\beta_{1} \mathrm{P}_{\mathrm{bbull}^{(t-3)}}+\beta_{2} \operatorname{Senin}_{(\mathrm{t}-3)}+\beta_{3} \operatorname{Selasa}_{(\mathrm{t}-3)}+\beta_{4} \operatorname{Rabu}_{(\mathrm{t}-3)}+\beta_{5} \operatorname{Kamis}_{(\mathrm{t}-3)}+\beta_{6} \operatorname{Jum}^{\prime} \mathrm{at}_{(\mathrm{t}-3)}+\dot{\varepsilon}_{(\mathrm{t}-3)} \ldots \ldots$ 3

$\operatorname{AR}_{(t-4)}=\alpha+\beta_{1} P_{b_{b u l l}(t-4)}+\beta_{2} \operatorname{Senin}_{(t-4)}+\beta_{3} \operatorname{Selasa}_{(\mathrm{t}-4)}+\beta_{4} \operatorname{Rabu}_{(\mathrm{t}-4)}+\beta_{5} \operatorname{Kamis}_{(\mathrm{t}-4)}+\beta_{6} \mathrm{Jum}^{\prime} \mathrm{at}_{(\mathrm{t}-4)}+\dot{\varepsilon}_{(\mathrm{t}-4)} \ldots \ldots$ 4

$\operatorname{AR}_{(t-5)}=\alpha+\beta_{1} P_{\text {bbull }(t-5)}+\beta_{2} \operatorname{Senin}_{(t-5)}+\beta_{3} \operatorname{Selasa}_{(t-5)}+\beta_{4} \operatorname{Rabu}_{(t-5)}+\beta_{5} \operatorname{Kamis}_{(t-5)}+\beta_{6} \mathrm{Jum}^{\prime} \operatorname{at}_{(t-5)}+\dot{\varepsilon}_{(t-5)} \ldots \ldots$ 5

$\mathrm{AR}_{(\mathrm{t})}=\alpha+\beta_{1} \mathrm{P}_{\mathrm{bbull}(\mathrm{t})}+\beta_{2} \operatorname{Senin}_{(\mathrm{t})}+\beta_{3} \operatorname{Selasa}_{(\mathrm{t})}+\beta_{4} \operatorname{Rabu}_{(\mathrm{t})}+\beta_{5} \mathrm{Kamis}_{(\mathrm{t})}+\beta_{6} \mathrm{Jum}^{\prime} \mathrm{at}_{(\mathrm{t})}+\dot{\varepsilon}_{(\mathrm{t})}$ 6

$\mathrm{AR}_{(\mathrm{t}+1)}=\alpha+\beta_{1} \mathrm{P}_{\text {bbull }_{(t+1)}}+\beta_{2} \operatorname{Senin}_{(t+1)}+\beta_{3} \operatorname{Selasa}_{(t+1)}+\beta_{4} \operatorname{Rabu}_{(\mathrm{t}+1)}+\beta_{5} \operatorname{Kamis}_{(t+1)}+\beta_{6} \mathrm{Jum}^{\prime} \mathrm{at}_{(\mathrm{t}+1)}+\dot{\varepsilon}_{(t+1)} \ldots$ 7

$\mathrm{AR}_{(t+2)}=\alpha+\beta_{1} \mathrm{P}_{\text {bbull(t+2) }}+\beta_{2} \operatorname{Senin}_{(t+2)}+\beta_{3} \operatorname{Selasa}_{(t+2)}+\beta_{4} \operatorname{Rabu}_{(t+2)}+\beta_{5} \operatorname{Kamis}_{(t+2)}+\beta_{6} \mathrm{Jum}^{\prime} \mathrm{at}_{(t+2)}+\dot{\varepsilon}_{(t+2)} \ldots$ 8

$\operatorname{AR}_{(t+3)}=\alpha+\beta_{1} P_{\text {bbull }(t+3)}+\beta_{2} \operatorname{Senin}_{(t+3)}+\beta_{3} \operatorname{Selasa}_{(t+3)}+\beta_{4} \operatorname{Rabu}_{(t+3)}+\beta_{5} \operatorname{Kamis}_{(t+3)}+\beta_{6} \operatorname{Jum}^{\prime}{ }^{\prime(t+3)}+\dot{\varepsilon}_{(t+3)} \ldots$ 9

$\mathrm{AR}_{(\mathrm{t}+4)}=\alpha+\beta_{1} \mathrm{P}_{\mathrm{bbull}_{(\mathrm{l}+4)}}+\beta_{2} \operatorname{Senin}_{(\mathrm{t}+4)}+\beta_{3} \operatorname{Selasa}_{(\mathrm{t}+4)}+\beta_{4} \operatorname{Rabu}_{(\mathrm{t}+4)}+\beta_{5} \operatorname{Kamis}_{(\mathrm{t}+4)}+\beta_{6} \mathrm{Jum}^{\prime} \mathrm{at}_{(\mathrm{t}+4)}+\dot{\varepsilon}_{(\mathrm{t}+4)} \ldots$ 10

$\operatorname{AR}_{(t+5)}=\alpha+\beta_{1} P_{\text {bbull }(t+5)}+\beta_{2} \operatorname{Senin}_{(t+5)}+\beta_{3} \operatorname{Selasa}_{(t+5)}+\beta_{4} \operatorname{Rabu}_{(t+5)}+\beta_{5} \operatorname{Kamis}_{(t+5)}+\beta_{6} \operatorname{Jum}^{\prime} \mathrm{at}_{(t+5)}+\dot{\varepsilon}_{(t+5) \ldots} \ldots$ 11

$\operatorname{AR}_{((t-1)}=\alpha+\beta_{1} P_{\text {jbear(t-1) }}+\beta_{2} \operatorname{Senin}_{(t-1)}+\beta_{3} \operatorname{Selasa}_{(t-1)}+\beta_{4} \operatorname{Rabu}_{(t-1)}+\beta_{5} \operatorname{Kamis}_{(t-1)}+\beta_{6} J_{\text {Jum'at }}$ at-1) $+\dot{\varepsilon}_{(t-1)} \ldots .$. 12

$\operatorname{AR}_{((t-2)}=\alpha+\beta_{1} P_{j b e a r(t-2)}+\beta_{2} \operatorname{Senin}_{(t-2)}+\beta_{3} \operatorname{Selasa}_{(t-2)}+\beta_{4} \operatorname{Rabu}_{(t-2)}+\beta_{5} \operatorname{Kamis}_{(t-2)}+\beta_{6} \operatorname{Jum}^{\prime} \mathrm{at}_{(t-2)}+\dot{\varepsilon}_{(t-2)} \ldots .$. 13

$\operatorname{AR}_{((t-3)}=\alpha+\beta_{1} P_{j b e a r(t-3)}+\beta_{2} \operatorname{Senin}_{(t-3)}+\beta_{3} \operatorname{Selasa}_{(t-3)}+\beta_{4} \operatorname{Rabu}_{(t-3)}+\beta_{5} \operatorname{Kamis}_{(t-3)}+\beta_{6} J_{u m}{ }^{\prime a t} t_{(t-3)}+\dot{\varepsilon}_{(t-3)} \ldots .$. 14

$\mathrm{AR}_{((t-4)}=\alpha+\beta_{1} \mathrm{P}_{j \text { bear(t-4) }}+\beta_{2} \operatorname{Senin}_{(\mathrm{t}-4)}+\beta_{3} \operatorname{Selasa}_{(\mathrm{t}-4)}+\beta_{4} \operatorname{Rabu}_{(\mathrm{t}-4)}+\beta_{5} \operatorname{Kamis}_{(\mathrm{t}-4)}+\beta_{6} \mathrm{Jum}^{\prime} \mathrm{tat}_{(\mathrm{t}-4)}+\dot{\varepsilon}_{(\mathrm{t}-4)} \ldots \ldots$ 15

$\operatorname{AR}_{((t-5)}=\alpha+\beta_{1} P_{j b e a r(t-5)}+\beta_{2} \operatorname{Senin}_{(t-5)}+\beta_{3} \operatorname{Selasa}_{(t-5)}+\beta_{4} \operatorname{Rabu}_{(t-5)}+\beta_{5} \operatorname{Kamis}_{(t-5)}+\beta_{6} \operatorname{Jum}^{\prime a t} t_{(t-5)}+\dot{\varepsilon}_{(t-5)} \ldots .$. 16

$\operatorname{AR}_{(t)}=\alpha+\beta_{1} P_{\text {jbear(t) }}+\beta_{2} \operatorname{Senin}_{(t)}+\beta_{3} \operatorname{Selasa}_{(t)}+\beta_{4} \operatorname{Rabu}_{(t)}+\beta_{5} \operatorname{Kamis}_{(t)}+\beta_{6} \operatorname{Jum}^{\prime} \operatorname{at}_{(t)}+\dot{\varepsilon}_{(t)} \ldots \ldots \ldots \ldots \ldots . . . . .$. 17

$\mathrm{AR}_{((t+1)}=\alpha+\beta_{1} \mathrm{P}_{\text {jbear }(t+1)}+\beta_{2} \operatorname{Senin}_{(t+1)}+\beta_{3} \operatorname{Selasa}_{(t+1)}+\beta_{4} \operatorname{Rabu}_{(t+1)}+\beta_{5} \operatorname{Kamis}_{(t+1)}+\beta_{6} \operatorname{Jum}^{\prime} \mathrm{Jat}_{(t+1)}$ $+\dot{\varepsilon}_{(t+1) \ldots 18}$

$\mathrm{AR}_{(\mathrm{t}+2)}=\alpha+\beta_{1} \mathrm{P}_{\mathrm{jbear}(\mathrm{t}+2)}+\beta_{2} \operatorname{Senin}_{(\mathrm{t}+2)}+\beta_{3} \operatorname{Selasa}_{(\mathrm{t}+2)}+\beta_{4} \operatorname{Rabu}_{(\mathrm{t}+2)}+\beta_{5} \operatorname{Kamis}_{(\mathrm{t}+2)}+\beta_{6} \operatorname{Jum}^{\prime} \mathrm{at}_{(\mathrm{t}+2)}$ $+\dot{\varepsilon}_{(\mathrm{t}+2) \ldots 19}$

$\operatorname{AR}_{((t+3)}=\alpha+\beta_{1} \mathrm{P}_{\text {jbear }(t+3)}+\beta_{2} \operatorname{Senin}_{(t+3)}+\beta_{3} \operatorname{Selasa}_{(t+3)}+\beta_{4} \operatorname{Rabu}_{(t+3)}+\beta_{5} \operatorname{Kamis}_{(t+3)}+\beta_{6} \operatorname{Jum}^{\prime} \mathrm{Jat}_{(t+3)}$ $+\dot{\varepsilon}_{(t+3)} \ldots .20$

$\operatorname{AR}_{((t+4)}=\alpha+\beta_{1} P_{j b e a r(t+4)}+\beta_{2} \operatorname{Senin}_{(t+4)}+\beta_{3} \operatorname{Selasa}_{(t+4)}+\beta_{4} \operatorname{Rabu}_{(t+4)}+\beta_{5} \operatorname{Kamis}_{(t+4)}+\beta_{6} J_{u m} \operatorname{Jat}_{(t+4)}+\dot{\varepsilon}_{(t+4)}$ $\ldots 21$ 
$\operatorname{AR}_{((t+5)}=\alpha+\beta_{1} P_{\text {jbear }(t+5)}+\beta_{2} \operatorname{Senin}_{(t+5)}+\beta_{3} \operatorname{Selasa}_{(t+5)}+\beta_{4} \operatorname{Rabu}_{(t+5)}+\beta_{5} \operatorname{Kamis}_{(t+5)}+\beta_{6} \operatorname{Jum}^{\prime a t} t_{(t+5)}+\dot{\varepsilon}_{(t+5)}$ $\ldots 22$

Model regresi 1 sampai 11 digunakan untuk menguji hipotesis 1 dan 2, sedang model 12 sampai 22 digunakan untuk menguji hipotesis 3 dan 4. Model-model ini menggunakan data time series. Variabel $\mathbf{A R}_{\mathbf{t}}$ dihitung dengan menggunakan rumus yang disarankan oleh Atkins \& Dyl (1990), yaitu:

Keterangan:

$$
\mathrm{AR}_{\mathrm{it}}=\mathrm{R}_{\mathrm{it}}-\mathrm{a}_{\mathrm{i}}-\mathrm{b}_{\mathrm{i}} \mathrm{R}_{\mathrm{Mt}}
$$

$\mathrm{AR}_{\mathrm{it}}$ : Abnormal return saham i pada periode $\mathrm{t}$

$\mathrm{R}_{\mathrm{it}}$ : Return saham i pada periode $\mathrm{t}$ (close to close)

$\mathrm{a}_{\mathrm{i}}$ : Intersep dari market-adjusted return yang dicari dengan rumus, $\mathrm{R}_{\mathrm{it}}=\mathrm{R}_{\mathrm{it}}+\mathrm{a}_{\mathrm{i}}+\mathrm{b}_{\mathrm{i}} \mathrm{R}_{\mathrm{Mt}}+\varepsilon_{\mathrm{it}}$

$\mathrm{R}_{\mathrm{Mt}}$ : Return market pada periode $\mathrm{t}$ (IHSG), dengan metode close-to-close

\section{HASIL DAN PEMBAHASAN}

Secara umum, posting berpengaruh terhadap abnormal return seperti yang diharapkan, namun tidak konsisten. Pengaruh tersebut ada yang positif dan ada pula yang negatif, baik pada sebelum hari posting $\left(\mathrm{t}_{-1-}-5\right)$ maupun setelah hari posting $\left(\mathrm{t}_{+1-5}\right)$. Selain tidak konsisten, pengaruh posting pada return saham sebagian besar juga tidak signifikan, baik pada kondisi pasar bullish maupun bearish (lihat Tabel 4 dan Tabel 5).

Tabel 4. Hasil Regresi Model 1-11

\begin{tabular}{|c|c|c|c|c|c|c|c|c|c|c|c|c|c|c|}
\hline \multicolumn{15}{|c|}{ ANTM - BULLISH } \\
\hline \multirow{2}{*}{ Var } & \multicolumn{2}{|c|}{$\mathrm{AR}$} & \multicolumn{2}{|c|}{ Posting Beli } & \multicolumn{2}{|c|}{ Senin } & \multicolumn{2}{|c|}{ Selasa } & \multicolumn{2}{|c|}{ Rabu } & \multicolumn{2}{|c|}{ Kamis } & \multicolumn{2}{|c|}{ Jumat } \\
\hline & $\alpha$ & $\mathrm{t}$ & $\beta 1$ & $\mathrm{t}$ & $\beta 2$ & $\mathrm{t}$ & $\beta 3$ & $\mathrm{t}$ & $\beta 4$ & $\mathrm{t}$ & $\beta 5$ & $\mathrm{t}$ & $\beta 6$ & $\mathrm{t}$ \\
\hline$t-5$ & 0.011 & 0.363 & -0.091 & -0.715 & -0.086 & -0.184 & -0.15 & -0.318 & -0.133 & -0.284 & -0.192 & -0.411 & -0.231 & -0.48 \\
\hline $\mathrm{t}-4$ & 0.021 & 0.733 & -0.046 & -0.358 & -0.268 & -0.559 & -0.321 & -0.688 & -0.314 & -0.666 & -0.37 & -0.792 & -0.42 & -0.899 \\
\hline$t-3$ & 0.022 & 0.781 & -0.144 & -1.132 & -0.269 & -0.578 & -0.35 & -0.734 & -0.317 & -0.682 & -0.387 & -0.825 & -0.426 & -0.917 \\
\hline$t-2$ & 0.029 & 1.048 & -0.368 & -3.047 & -0.336 & -0.761 & -0.392 & -0.888 & -0.395 & -0.872 & -0.443 & -1.004 & -0.52 & -1.167 \\
\hline$t-1$ & 0.001 & 0.028 & -0.088 & -0.766 & 0.066 & 0.157 & 0.016 & $0.038 * *$ & 0.047 & 0.108 & -0.038 & -0.091 & -0.085 & -0.202 \\
\hline $\mathrm{t}$ & -0.014 & -0.503 & 0.24 & 1.926 & 0.264 & 0.58 & 0.225 & 0.49 & 0.232 & 0.51 & 0.146 & 0.321 & 0.102 & 0.218 \\
\hline$t+1$ & 0.015 & 0.616 & 0.234 & 2.083 & -0.2 & -0.486 & -0.264 & -0.643 & -0.233 & -0.578 & -0.326 & -0.792 & -0.414 & -0.984 \\
\hline$t+2$ & 0.001 & $0.028 * *$ & 0.118 & 1.016 & 0.03 & 0.071 & -0.009 & $-0.022^{* *}$ & 0.011 & $0.025 * *$ & -0.07 & -0.168 & -0.147 & -0.348 \\
\hline$t+3$ & 0.015 & 0.594 & 0.02 & 0.172 & -0.195 & -0.465 & -0.237 & -0.553 & -0.218 & -0.522 & -0.297 & -0.693 & -0.367 & -0.859 \\
\hline$t+4$ & 0.015 & 0.591 & 0.03 & 0.257 & -0.194 & -0.461 & -0.243 & -0.577 & -0.224 & -0.531 & -0.297 & -0.69 & -0.37 & -0.861 \\
\hline$t+5$ & 0.001 & $0.028 * *$ & 0.183 & 1.554 & 0.011 & $0.025 * *$ & -0.022 & -0.054 & -0.014 & $-0.034 * *$ & -0.109 & -0.26 & -0.151 & -0.353 \\
\hline
\end{tabular}

Untuk kondisi pasar bullish, pengaruh positif posting beli pada abnormal return hanya terjadi hari posting dan lima hari setelah posting $\left(\mathrm{t}_{0}, \mathrm{t}_{+1-5}\right)$. Namun dari semua pengaruh positif tersebut, tak ada satu pun yang signifikan. Dengan demikian, dapat diambil kesimpulan sementara bahwa posting beli pada kondisi pasar bullish tidak signifikan mempengaruhi abnormal return saham di BEI. Sebagai konsekuensinya, hipotesis pertama $\left(\mathrm{H}_{1}\right)$ tidak dapat dibuktikan. Dengan kata lain, gosip di media sosial 
tidak dapat dimanfaatkan untuk memprediksi imbal hasil saham di BEI. Dapat dikatakan, pada kondisi pasar bullish, orang-orang banyak bergosip namun tidak dapat mendapatkan hasil dari investasinya.

Bagaimana dengan persistensi atau ketahanan gosip dalam mempengaruhi return saham? Secara umum, persistensi posting beli pada konsisi pasar bullish yang menurun kemampuannya mempengaruhi return saham, baik sebelum posting maupun sesudahnya. Pada saat posting $\left(\mathrm{t}_{0}\right)$ nilai koefisien pengaruh $(\beta)$ sebesar 0,240. Angka ini menurun menjadi $-0,088$ pada $t_{-1}$ dan menjadi $-0,091$ pada $t_{-5}$. Selanjutnya, pada periode setelah posting, misalnya apda $\mathrm{t}_{+1}$, koefisien menunjuk angka 0,234 atau menurun sedikit dari $\mathrm{t}_{0}$, dan menurun lagi menjadi 0,183 pada $\mathrm{t}_{+5}$.

Posting beli masih memiliki pengaruh yang positif terhadap return saham, yang mana hal ini berarti masih seperti yang diharapkan, meskipun tidak signifikan. Sebaliknya, harihari bursa justru menunjukkan kebalikannya. Sebagian besar koefisien pada hari-hari bursa memberikan angka negatif. Hal ini berarti bahwa hari-hari bursa sama sekali tidak seperti yang diharapkan, yaitu memiliki pengaruh positif terhadap return saham dan juga tidak signifikan. Kesimpulan sementara yang diperoleh adalah bahwa hari-hari bursa tidak dapat digunakan sebagai alat prediksi atas return saham di BEI.

Memang ada beberapa hari bursa yang masih menunjukkan pengaruh signifikan, tetapi amat sedikit, yaitu hari Senin, Selasa dan Rabu. Untuk hari bursa Senin, pengaruh signifikan dirasakan pada $t_{+5}$, yaitu sebesar 0,025 . Pada $t_{+5}$ ini pun koefisien pengaruh hari Senin positif. Jadi hal ini telah sesuai dengan hipotesis. Untuk hari Selasa, pengaruh signifikan dirasakan pada $t_{-1}$, yaitu sebesar 0,038 , dengan koefisien pengaruh yang juga positif atau sesuai dengan hipotesis. Untuk hari Selasa pada $t_{+2}$, meskipun memiliki pengaruh signifikan, namun pengaruh tersebut adalah negative, dengan nilai signifikansi yang juga negatif. Sehingga hal ini tidak sesuai dengan hipotesis. Hal yang sama juga terjadi pada hari Rabu pada $\mathrm{t}+5$, koefisien pengaruh dengan nilai signifikansi yang bertanda negatif, yakni -0,014 dan -0,034.

Untuk persistensi, sepertinya pengaruh hari-hari bursa juga sama dengan pengaruh posting, yakni semakin menurun, baik pada periode sebelum posting maupun periode setelah posting. Dengan hasil seperti ini, maka dapat ditarik kesimpulan sementara bahwa hipotesis satu tidak dapat dibuktikan. Untuk hipotesis ketiga, masih ada beberapa yang terbukti, yaitu hari Senin pada $t_{+5}$ dan Selasa pada $t_{-1}$. Kemudian dari sisi persistensi pengaruh, dapat dikatakan bahwa ketahanan pengaruh tersebut semakin menurun seiring dengan berjalannya waktu.

Untuk kondisi pasar bearish, hasil yang diperoleh tidak berbeda dengan hasil pada kondisi pasar bullish. Secara umum, banyak hipotesis yang tidak terbukti. Hal ini karena posting jual dan hari-hari bursa banyak yang tidak signifikan mempengaruhi return saham. Meski demikian, secara umum hasil regresi pada kondisi pasar bearish adalah lebih baik daripada hasil regresi pada kondisi pasar bullish.

Untuk variabel utama, posting jual pada kondisi pasar bearish, hanya satu periode yang menunjukkan adanya signifikansi, yaitu pada t-4. Pada periode ini, koefisien ( $\beta$ ) adalah -0.001 dengan nilai signifikansi -0.008. Dengan demikian, hipotesis bahwa posting jual yang terjadi pada kondisi pasar bearish tidak dapat dibuktikan. Bahkan hasil tersebut menunjukkan kebalikan dari hipotesis semula.

Untuk pengaruh hari bursa, justru menarik untuk dicermati karena sebagian besar hari bursa pada kondisi pasar bearish ini justru signifikan dalam mempengaruhi return saham, yaitu pada hari Selasa, Rabu, Kamis dan Jum'at, meskipun tidak semua periode bersifat 
signifikan. Pada hari Selasa, misalnya, hanya periode $t_{-1}$ yang secara signifikan mempengaruhi return saham. Koefisien $\beta$ untuk periode $t_{-1}$ ini adalah 0,019 dengan nilai signifikansi 0,044. Dengan demikian, hasil ini menunjukkan bahwa hipotesis keempat, yakni hari bursa yang berpengaruh terhadap return saham dapat dibuktikan pada periode $\mathrm{t}$. 1 ini. Hal seperti ini, juga terjadi pada Jum'at.

Untuk hari Rabu, periode $t_{-1}$, koefisien $\beta$ adalah -0,044 dengan nilai signifikansi 0,104 . Hal ini berarti bahwa pengaruh hari Rabu pada periode $t_{-1}$ adalah signifikan pada $\alpha$ $=0,05$. Namun sayangnya, nilai signifikansi ini bertanda negatif. Dengan hasil seperti ini, maka periode $\mathrm{t}_{-1}$ pada hari Rabu tidak dapat dibuktikan hipotesisnya, dan bahkan hasil ini berlawanan dengan hipotesis semula. Hal yang sama juga terjadi pada hari bursa Rabu periode $t_{+5}$.

Pada akhirnya, hari Kamis memiliki dua periode yang signifikan mempengaruhi return saham, yaitu periode t-3 dan t-5. Namun sayang, kedua periode ini memiliki koefisien $\beta$ dan nilai signifikansi yang negatif, yang menunjukkan bahwa hipotesis yang dibangun tidak dapat disimpulkan karena hasil regresi menunjukkan arah yang berlawanan dengan hipotesis. Untuk periode $\mathrm{t}-3$, koefisien $\beta$ dan nilai signifikansi masing-masing adalah $-0,017$ dan $-0,04$. Sedang untuk periode $t-5$, koefisien $\beta$ dan signifikansinya masing-masing adalah -0,004 dan -0,0114.

Tabel 5. Hasil Regresi Model 12-22

\begin{tabular}{|c|c|c|c|c|c|c|c|c|c|c|c|c|c|c|}
\hline \multicolumn{15}{|c|}{ BUMI - BEARISH } \\
\hline \multirow{2}{*}{$\operatorname{Var}$} & \multicolumn{2}{|r|}{ AR } & \multicolumn{2}{|c|}{ Posting Beli } & \multicolumn{2}{|c|}{ Senin } & \multicolumn{2}{|c|}{ Selasa } & \multicolumn{2}{|c|}{ Rabu } & \multicolumn{2}{|c|}{ Kamis } & \multicolumn{2}{|c|}{ Jumat } \\
\hline & $\alpha$ & $\mathrm{t}$ & $\beta 1$ & $\mathrm{t}$ & $\beta 2$ & $\mathrm{t}$ & $\beta 3$ & $\mathrm{t}$ & $\beta 4$ & $\mathrm{t}$ & $\beta 5$ & $\mathrm{t}$ & $\beta 6$ & $\mathrm{t}$ \\
\hline$t-5$ & 0.008 & 0.308 & 0.019 & 0.154 & -0.094 & -0.223 & -0.189 & -0.449 & -0.23 & -0.543 & -0.004 & $-0.01 * * *$ & -0.134 & -0.329 \\
\hline $\mathrm{t}-4$ & -0.013 & $-0.049 * *$ & -0.001 & $-0.008 * *$ & 0.245 & 0.582 & 0.139 & 0.33 & 0.103 & 0.246 & 0.325 & 0.767 & 0.192 & 0.457 \\
\hline $\mathrm{t}-3$ & 0.009 & 0.345 & 0.023 & 0.187 & -0.099 & -0.234 & -0.172 & -0.407 & -0.239 & -0.568 & -0.017 & $-0.04 * *$ & -0.158 & -0.373 \\
\hline $\mathrm{t}-2$ & -0.025 & -0.946 & -0.064 & -0.527 & 0.457 & 1.081 & 0.365 & \begin{tabular}{|l|}
0.869 \\
\end{tabular} & 0.314 & 0.748 & 0.512 & 1.219 & 0.384 & 0.916 \\
\hline $\mathrm{t}-1$ & -0.001 & $-0.047 * *$ & -0.072 & -0.583 & 0.073 & 0.172 & 0.019 & $0.044 * *$ & -0.044 & $-0.104 *$ & 0.113 & 0.267 & 0.011 & $0.027 * *$ \\
\hline $\mathrm{t}$ & -0.02 & -0.736 & 0.093 & 0.761 & 0.347 & 0.822 & 0.261 & 0.619 & 0.189 & 0.446 & 0.379 & 0.897 & 0.302 & 0.717 \\
\hline$t+1$ & -0.033 & -1.218 & 0.048 & 0.388 & 0.513 & 1.211 & 0.49 & 1.184 & 0.421 & 0.995 & 0.572 & 1.342 & 0.498 & 1.175 \\
\hline$t+2$ & -0.023 & 0.866 & 0.175 & 1.425 & 0.344 & 0.812 & 0.342 & 0.826 & 0.292 & 0.707 & 0.428 & 1.011 & 0.288 & 0.678 \\
\hline$t+3$ & 0.038 & 1.401 & 0.095 & 0.762 & -0.605 & -1.406 & -0.58 & -1.386 & -0.625 & -1.496 & -0.508 & \begin{tabular}{|l|}
-1.217 \\
\end{tabular} & \begin{tabular}{|l|}
-0.587 \\
\end{tabular} & -1.373 \\
\hline$t+4$ & 0.025 & 0.943 & 0.201 & 1.607 & \begin{tabular}{|l|}
-0.398 \\
\end{tabular} & -0.933 & -0.464 & -1.104 & -0.467 & -1.119 & \begin{tabular}{|l|}
-0.329 \\
\end{tabular} & -0.79 & \begin{tabular}{|l|}
-0.401 \\
\end{tabular} & -0.962 \\
\hline$t+5$ & -0.005 & -0.183 & 0.137 & 1.07 & 0.096 & 0.225 & 0.061 & 0.144 & -0.038 & $-0.088^{*}$ & 0.114 & 0.267 & 0.049 & 0.116 \\
\hline
\end{tabular}

Hasil dari prediksi mengenai eksistensi gosip di media sosial pada nilai-nilai saham yang tidak signifikan, tidaklah mengejutkan. Hasil ini dapat berarti sesuai atau melengkapi hasil-hasil dari studi sebelumnya, yang memprediksikan bahwa informsi yang berasal dari diskusi di internet tidak memiliki arti bagi keputusan investasi (misalnya, Das \& Chen, 2001 dan Das et. al, 2005). Antwiler \& Frank (2004) mengistilahkannya sebagai: all that talk is just noise.

Hal yang menarik adalah justru pengaruh hari bursa menunjukkan keberadaannya. Untuk kondisi pasar bullish, terdapat tiga hari bursa yang signifikan mempengaruhi return saham, yaitu Senin, Selasa dan Rabu. Namun dari ketiga hari bursa tersebut, hanya dua hari bursa yang dapat mendukung kesimpulan, yaitu hari bursa Senin dan Selasa. Kedua hari bursa ini memberikan koefisien dan nilai signinfikansi yang positif. Meski demikian, 
hari bursa yang masih dapat digunakan sebagai prediksi terhadap return saham hanyalah hari bursa Senin. Hal ini terjadi karena pada hari bursa Senin terdapat pengaruh yang positif dan signifikan pada periode $\mathrm{t}_{+5}$, yaitu periode setelah terjadinya posting. Untuk hari bursa Selasa, meskipun masih dapat digunakan sebagai perdiktor, namun terjadi pada periode sebelum terjadinya posting, yaitu $\mathrm{t}_{-1}$. Hal ini tentu menyulitkan untuk mengambil kesimpulan bahwa berinvestasi sebelum posting dilakukan justru akan memberikan return yang menarik.

Pada kondisi pasar bearish, hari bursa yang berpengaruh signifikan semakin banyak, yaitu empat hari bursa (Selasa, Rabu, Kamis dan Jum'at). Yang menarik, sebagian besar hari bursa yang berpengaruh dan signifikan tersebut terjadi pada periode $t_{-1}$, yang terjadi pada hari Selasa, Rabu dan Jum'at. Bahkan, pada periode $t_{-1}$ tersebut, hari bursa Selasa dam Jum'at memberikan koefisien dan nilai signifikansi yang positif. Hal ini mengulangi kejadian pada kondisi pasar bullish, yaitu menyulitkan untuk mengambil kesimpulan bahwa amatlah kecil kemungkinan investasi dilakukan pada sehari sebelum dilakukan posting agar mendapatkan return saham.

Hal lain yang menarik dari hari bursa ini adalah, dari hari-hari bursa yang berpengaruh signifikan terhadap return saham, ada hari-hari bursa yang konsisten berpengaruh pada dua kondisi pasar, yaitu hari bursa Selasa dan Rabu. Selanjutnya, dari dua hari bursa yang secara konsisten berpengaruh signifikan tersebut, yang memiliki pengaruh positif dan nilai signifikansi positif hanyalah pada hari bursa Selasa.

Dengan demikian dapatlah diambil kesimpulan sementara, bahwa hari bursa Selasa pada periode $\mathrm{t}_{-1}$, dapat digunakan sebagai acuan untuk melakukan investasi yang menguntungkan (memberi return saham yang baik), meskipun kesimpulan seperti ini amat sulit untuk diterima. Sedangkan yang paling masuk akal adalah hari bursa Senin pada periode $\mathrm{t}_{+5}$, pada kondisi pasar bullish, yang dapat dijadikan dasar untuk melakukan investasi yang dapat memberikan return saham, karena periode $\mathrm{t}_{+5}$ terjadi pasca posting dilakukan.

Kemudian dari segi persistensi (lamanya dampak) posting, tidak dapat diketahui polanya, terutama pada periode pasar bullish. Hal ini dapat dilihat dari perubahan koefisien yang tidak teratur. Saat posting beli dilakukan (t), misalnya, koefisiennya adalah 0,24 . Koefisien ini menurun menjadi $-0,088$ pada $t_{-1}$ dan $-0,368$ pada $t_{-2}$. Namun kemudian koefisien ini naik lagi menjadi $-0,144$ pada periode $t_{-3}$. Pola yang sama juga terjadi pada periode setelah posting.

Untuk kondisi pasar bearish, pola persistensinya lebih jelas, yakni ada kecenderungan menguat, baik pada periode sebelum posting maupun sesudahnya. Dengan demikian, dapat dikatakan bahwa pengaruh posting bertahan lebih lama pada kondisi pasar bearish. Pada periode $\mathrm{t}$, koefisien pengaruh posting jual adalah 0,093. Angka ini terus menurun, bahkan bernilai negatif, sampai akhirnya kembali menjadi positif pada periode $t_{+5}$. Untuk periode $\mathrm{t}_{+1}$, koefisien posting jual adalah sebesar $-0,072$, berikutnya pada periode $t_{+2}$ naik menjadi 0,064 , dan naik lagi menjadi 0,023 pada periode $t_{+3}$. Untuk periode $t_{+4}$, persistensi menurun yang ditandai dengan menurunya koefisien menjadi $-0,001$, dan akhirnya naik kembali menjadi 0,019 pada periode $\mathrm{t}_{+5}$.

Pada periode setelah posting dalam kondisi pasar bearish, fenomena menunjukkan bertahannya pengaruh posting jual, meskipun dengan nilai yang fluktuatif. Pada periode $\mathrm{t}_{+1}$, koefisien menurun menjadi 0,048 dan selanjutnya meningkat lagi menjadi 0,175 pada periode $t_{+2}$. Berikutnya koefisien kembali menurun dengan nilai 0,095 pada periode $t_{+3}$, 
dan naik lagi menjadi 0,201 pada periode $t_{+4}$, yang kemudian diakhiri dengan kembali menurun menjadi 0,137 pada periode $t_{+5}$.

Dari hasil seperti itu teranglah, bahwa tidak memungkinkan bagi investor untuk mengandalkan informasi dari internet untuk mendapatkan keuntungan dengan cara melakukan posting informasi di internet sebelum mengambil keputusan berinvestasi (beli ataupun jual). Justru kemungkinan apa yang ditemukan dari penelitian terdahulu (misalnya, Tumarkin \& Whitelaw, 2001; Das \& Chen, 2001; Antweiler \& Frank, 2002; 2004), bahwa tidak ada bukti sentimen yang dapat digunakan untuk memprediksi return saham di masa depan, lebih besar kemungkinannya untuk mendapatkan kebenaran. Bahkan Das et. al, 2005, berkesimpulan bahwa investor tidak melakukan posting terlebih dahulu untuk kemudian melakukan investasi, namun sebaliknya investor memperhatikan kinerja nilai saham terlebih dahulu untuk kemudian melakukan posting. Mengikuti hasil temuan dari Das et. al, 2005 tersebut, temuan di dalam penelitian ini memungkinkan untuk diambil kesimpulan bahwa investor melakukan investasi terlebih dahulu, baru kemudian melakukan pembicaraan di internet. Hal ini dibuktikan melalui koefisien positif dan nilai signifikansi dari pengaruh hari Selasa pada periode $t_{-1}$ pada kedua kondisi pasar. Bahkan pada kondisi pasar bearish, terdapat dua hari bursa yang memiliki signifikansi untuk periode posting $\mathrm{t}_{-1}$, yakni hari Rabu dan Jum'at. Lebih jauh lagi, untuk hari bursa Jum'at, koefisien dan nilai signifikansi pada periode $\mathrm{t}_{-1}$ bertanda positif. Hal ini berarti bahwa investor pada hari Jum'at melakukan investasi, sehari sebelum melakukan pembicaraan melalui internet (bergosip melalui media sosial).

\section{PENUTUP}

Simpulan. Penelitian ini mengajukan permasalahan apakah benar gosip di media sosial dapat menentukan return saham? Apabila dapat, seberapa lama keberadaan dari pengaruh gosip tersebut? Apakah justru yang menentukan return saham tersebut sebenarnya adalah hari bursa? Apabila ya, berapa lama pula ketahanannya?

Jawaban atas permasalahan pertama adalah gosip di media sosial tidak dapat digunakan sebagai penentu return saham. Simpulan seperti ini dapat diambil setelah hipotesis pertama dari penelitian ini tidak dapat dibuktikan, yaitu dengan tidak signifikannya pengaruh posting beli dan jual terhadap return saham pada kondisi pasar bullish dan bearish.

Meskipun sudah dapat ditarik simpulan bahwa gosip di media sosial tidak dapat digunakan untuk memprediksi return saham, namun persistensi keberadaan gosip tersebut masih dapat ditemukan jejaknya, meskipun dengan pola yang tidak konsisten.

Selanjutnya, justru hari-hari bursa berpotensi untuk digunakan sebagai penentu return saham. Hal ini ditandai dengan adanya pengaruh signifikan dari beberapa hari bursa terhadap return saham. Meskipun demikian, kesimpulan seperti ini sebenarnya amat sulit untuk diterima, sebab pengaruh yang signifikan tersebut justru terjadi pada periode sebelum posting dilakukan. Satu-satunya pengaruh hari bursa setelah posting dilakukan adalah hari bursa Senin pada periode $\mathrm{t}_{+5}$, pada kondisi pasar bullish.

Konsistensi hari bursa Selasa pada periode t-1, pada kondisi pasar bullish dan bearish, berpotensi menghasilkan simpulan bahwa investor melakukan investasi dan memetik keuntungan terlebih dahulu, baru kemudian menyebarkan gosip melalui media sosial. Hal ini menarik untuk dilakukan peneltian lebih lanjut. 
Saran. Dari hasil simpulan diatas, ada beberapa saran yang dapat diberikan. Pertama, secara teoritis diperoleh hasil bahwa posting tidak mempengaruhi return saham secara signifikan. Dengan demikian, hasil ini berada di sisi penelitian-penelitian yang mengklaim bahwa tidak terdapat pengaruh dari informasi yang diperoleh dari media sosial terhadap nilai-nilai saham. Hasil seperti ini masih memerlukan pengujian lebih lanjut tentang manfaat informasi yang diperoleh dari media sosial, sebab hal ini akan membuka peluang untuk menyimpulkan bahwa telah terjadi efisiensi di BEI, sesuai dengan efficient market hypothesis, yang menyatakan bahwa informasi publik tidak dapat digunakan untuk memprediksi nilai-nilai saham.

Kedua, secara empiris. Bagi investor yang telah memanfaatkan fasilitas internet, tidak memungkinkan memanfaatkan gosip yang diperoleh dari internet untuk mendapatkan keuntungan. Sebaliknya, dengan berinvestasi berdasarkan hari bursa, investor justru lebih berpotensi untuk memperoleh return saham.

Ketiga, untuk penelitian lanjutan. Berangkat dari temuan empiris, investor yang berinvestasi di hari bursa Senin pada periode $\mathrm{t}_{+5}$, pada periode pasar bullish, lebih memungkinkan untuk mendapatkan abnormal return, dibandingkan dengan mem-posting gosip di internet. Hal ini menarik untuk diselidiki lebih lanjut, yakni apakah hal ini terjadi sebagai akibat dari adanya kemungkinan anomali week-end effect. Apalagi, pengaruh hari Senin juga lebih besar dibandingkan dengan hari-hari bursa lainnya. Penelitian lanjutan lainnya adalah menggunakan gosip di media sosial untuk menguji fenomena Efficient Market Hypothesis (EMH) yang terjadi di BEI. Hal lain yang menarik untuk dilakukan penelitian lebih lanjut adalah pengujian atas kebenaran dari hasil temuan penelitian ini, yaitu bahwa investor melakukan investasi terlebih dahulu, baru kemudian melakukan posting di media sosial.

\section{DARTAR RUJUKAN}

Antweiler, Werner and Murray Z. Frank (2002). Internet stock message boards and stock return. Working Paper. University of British Columbia.

(2004a). Is All That Talk Just Noise? The information content of internet stock message boards. Journal of Finance, 59 (3): 1.259-1.294.

(2004b). Does Talk Matter? Evidence from a broad cross-section of stocks. Working paper. University of British Columbia.

Atkins, Allen B. and Edward A. Dyl (1990). Price reversals, bid-ask spreads, and market efficiency. Journal of Financial and Quantitative Analysis, 25 (4): 535-547.

Barber, Brad M. and Terrance Odean. (2000). Trading is hazardous to your wealth: The common stock investment performance of individual investors. Journal of Finance, 55 (2): 773-806.

Crawford, Alan P. (1999). When those nasty rumors start breeding on the web, you've got to move fast. Public Relations Quarterly, 44 (4):43-45.

Das, Sanjiv R. and Mike. Y. Chen (2001). Yahoo! for Amazon: Sentiment parsing from small talk on the web. Working Paper. Santa Clara University.

Das, Sanjiv R., Asis Martinez-Jerez, and Peter Tufano. (2005). eInformation: Clinical study of investor discussion and sentiment. Financial Management. 34 (3), 103 137.

Dewally, Michael. (2003). Internet investment advice: Investing with a rock of salt. Financial Analysts Journal, 59 (4): 65-83. 
DiFonzo, N. and P. Bordia (1997). Rumor and prediction: Making sense (but losing Dollars) in the stock market. Organizational Behavior and Human Decision Processes, 71 (3): 329-353.

Epstein, Marc J. and Moses L. Pava (1994). Individual investor's perceptions on the summary annual report: A survey approach. Journal of Applied Business Research, 10 (3): 60-67.

Felton, James and Jong Chai Kim (2002). Warnings from the Enron Message Board. Journal of Investing 11 (2): 29-53.

Fisher, Kenneth L. and Meir Statman (2000). Investor sentiment and stock returns. Financial Analysts Journal, 56 (2): 16-23.

Harmon, Amy (1998, 1 September). Investor Online. The New York Time, 6.

Hawkins, D. and B. Hawkins (1986). The Effectiveness of the Annual Report as a Communication Vehicle. Morristown, NJ: Financial Executives Research Foundation.

Hodge, F. and M. Pronk. (2006). The impact of expertise and investment familiarity on investors' use of online financial report information. Working paper, University of Washington, 38.

Jones, Charles P. (2004). Investments: Analysis and Management. New Jersey: John Wiley \& Sons.

JuniorTrader@yahoogroups.com

Kimmel, A. J. (2004). Rumors and the financial market place. The Journal of Behavioral Finance, 5 (3): 134-141.

Koenig, Frederick W. (1985). Rumor in the Marketplace. Dover MA: Auburn House Publishing.

Leinweber, David J. and Ananth N Madhavan (2001). Three hundred years of stock market manipulations. Journal of Investing, 10 (2): 7-16.

Rose, Jacob M. (2001). The effects of multimedia-induced affective states on recall and decision-making by individual investors. International Journal of Accounting Information Systems (2): 22-40.

Rose, Jacob M., F. D. Roberts, and A. M. Rose. (2004). Affective responses to financial data and multimedia: The effects of information load and cognitive load. International Journal of Accounting Information Systems (5): 5-24.

Rosnow, Ralph. L. (1988). Rumor as communication: A contextualist approach. Journal of Communication, 38 (1): 12-28.

496. (1991). Inside rumor: A personal journey. American Psychologist, 46 (5): 484(2001). Rumor and Gossip in Interpersonal Interaction and Beyond: A Social Exchange Perspective. In R. M. Kowalski (Ed.), Behaving Badly: Aversive Behaviors in Interpersonal Relationships, pp: 203-232. Washington, DC: American Psychological Association.

Sehgal, Vivek and Charles Song. (2007). SOPS: Stock prediction using web sentiment. IEEE International Conference on Data Mining Workshops, Omaha, NE, USA, 2007, pp. 21-26.

Tumarkin, Robert and Robert F. Whitelaw. (2001). News or noise? Internet message board activity and stock prices. Financial Analysts Journal, 57 (3): 41-51.

Wert, Sarah R., and Peter Salovey. (2004). Introduction to the special issue on gossip. Review of General Psychology, 8, 76-77. 
Wysocki, Peter D. (1998). Cheap talk on the web: The determinants of posting on internet stock message boards. Working Paper. University of Michigan Business School. November.

Wysocki, Peter D. (1999). Short-seller and message posting activity on the web. Working Paper, University of Michigan Business School. October.

Yahoo Upgrades Finance Portal. (2006). Red Herring, April 4, 2006. 